Plant Tissue Cult. \& Biotech. 22(2): 107-111, 2012 (December)

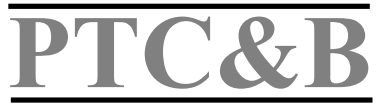

\title{
In vitro Seed Germination and Seedling Development of Esmeralda clarkei Rchb.f. (Orchidaceae)
}

\author{
M. Paudel, S. Pradhan and B. Pant* \\ Bhairahawa Multiple Campus, Tribhuvan University, Bhairahawa, Rupandehi, Nepal \\ Key words: Esmeralda clarkei, In vitro, Protocorm, Seedling
}

\begin{abstract}
Esmeralda clarkei Rchb.f. (Orchidaceae), an epiphytic orchid native to Nepal with high ornamental value grows from cool to intermediate climatic conditions with medium amount of light. In an attempt to preserve this important orchid by establishing an efficient in vitro regeneration protocol using seed culture was conducted. MS with BAP and NAA alone or in combination were used. In MS protocorms developed within 16 weeks followed by seedling development in 25 weeks of seed culture. Presence of BAP $(0.5 \mathrm{mg} / \mathrm{l})$ in MS improved seed germination by protocorm formation and seedling development in 17 and 26 weeks of seed culture, respectively. In $0.5 \mathrm{mg} / \mathrm{l}$ NAA supplemented media, development of protocorms was observed in 18 weeks and seedling growth was observed in 26 weeks of seed culture. Protocorm and seedling development were as-delayed in other media.
\end{abstract}

\section{Introduction}

Orchid seeds are characterized by lack of storage tissues required for seed germination and seedling development. In nature, association with a specific fungal partner is a pre-requisite for orchid seed germination (Mitra 1986). However, the rate of vegetative propagation is very slow and the seed germination in nature is very poor, i.e, $0.2-0.5 \%$ (Vij 2002). In vitro germination of seeds is an important aspect in the orchid multiplication and conservation program since the dust like tiny seeds have the capability of developing into complete seedlings without any fungal aid. Knudson (1922) demonstrated the possibility of by-passing the fungal requirement of orchid seeds during in vitro germination and since then non-symbiotic seed germination has been accepted as an important tool for propagating orchids (Arditti et al. 1982).

*Author for correspondence. Central Department of Botany, Tribhuvan University, Kirtipur, Kathmandu, Nepal. <pant_bijaya@yahoo.com>. 
E. clarkei is an epiphytic orchid native to Nepal with a high ornamental value grows on Rhododendron species from cool to mild climatic conditions with medium amount of light. Plants bloom from fall to winter with three to four fragrant flowers (Fig. 1) (Ghimire 2008). The species is under threat due to removal of their natural habitat for 'Slash and Burn' cultivation, unplanned developmental activities and deforestation. No information is available on the seed germination and protocorm development of E. clarkei. In this paper, authors have developed an efficient seed germination protocol for E. clarkei that facilitates protocorm development and in vitro seedling development.

\section{Materials and Methods}

The green healthy capsule of $\boldsymbol{E}$. clarkei (Orchidaceae) collected from the natural plant grown in primary forest of Gaurishankar Conservation Area, Lamabagar V.D.C.-9, Chhetchhet (alt. 1330, lat. 27052.713', long. 86013.263'), Dolakha, eastern Nepal was used.

Capsule of E. clarkei was dipped in water containing a few drops of teepol solution. Then, they were washed with running tap water for $30-40 \mathrm{~min}$ and thereafter rinsed with distilled water. The pod was then wrapped with cotton, dipped in $70 \%$ ethyl alcohol for $1 \mathrm{~min}$ and surface sterilized in $1 \%$ sodium hypochlorite solution for $10 \mathrm{~min}$. Finally they were rinsed 3 - 5 times with sterile water.

MS was used as the basal medium either alone or supplemented with different concentrations and combinations of NAA and BAP for the inoculation of seeds. Medium was adjusted to $\mathrm{pH} 5.8$ before autoclaving and solidified with $0.8 \% \mathrm{w} / \mathrm{v}$ Difco Bacto Agar. About $20 \mathrm{ml}$ medium per culture tube was dispensed into culture tubes (large sized capacity of $80 \mathrm{ml}$ ) and each tube was tightly covered with aluminum foil. The culture tubes containing the medium were autoclaved at $121^{\circ} \mathrm{C}$ and pressure of $15 \mathrm{lb} / \mathrm{sq}$ inch for $20 \mathrm{~min}$. After cooling down, the tubes were taken out and kept in slanting position in the culture room.

The surface sterilized orchid capsule was then transferred into the laminar air flow cabinet and dissected longitudinally by using sterile scalpel. Immature orchid seeds in cluster were inoculated on the surface of MS alone and in combination with NAA $(0.5 \mathrm{mg} / \mathrm{l})$ and BAP $(0.5-2.0 \mathrm{mg} / \mathrm{l})$ using sterile forceps. The cultures were incubated at $25 \pm 2^{\circ} \mathrm{C}$ under the photoperiod of $16 \mathrm{hrs}$.

\section{Results and Discussion}

Immature seeds of E. clarkei showed varied response depending upon different plant hormones employed at varied concentrations of BAP $(0.5-2.0 \mathrm{mg} / \mathrm{l})$ and 
NAA $(0.5 \mathrm{mg} / \mathrm{l})$ either individually and in combinations. In most of the tested media, germination of seeds was seen within 7 to 9 weeks, protocorms development within 16 to 20 weeks followed by shoots formation in 25 to 27 weeks (Table 1). In MS without plant hormones protocorms developed within 16 weeks of seed culture (Fig. 2) giving rise to seedlings after 25 weeks of culture. Similar results were reported in Habenaria macroceratits (Stewart and Kane 2006), Eulophia alta (Johnson et al. 2007). The protocorms were round, oval, elongated bodies considered as an intermediate structure between the embryos and the plants. These protocorms underwent further morphogenetic changes resulting in the development of leaf primordia and finally to the seedlings in 25 weeks in MS basal medium. Nayak et al. (1998) reported regeneration of Cymbidium aloifolium by using rhizomes that developed from the immature seeds when grown on MS medium supplemented with different growth regulators.

Table 1. Effect of BAP and NAA on in vitro seeds germination and seedling development of E. clarkei.

\begin{tabular}{|c|c|c|c|c|}
\hline \multicolumn{2}{|c|}{ Concentrations } & \multirow{2}{*}{$\begin{array}{c}\text { Germination } \\
\text { initiation in weeks } \\
(\text { Mean } \pm \text { SE })\end{array}$} & \multirow{2}{*}{$\begin{array}{c}\text { Protocorms } \\
\text { formation in weeks } \\
(\text { Mean } \pm \text { SE })\end{array}$} & \multirow{2}{*}{$\begin{array}{c}\text { Seedling } \\
\text { development in } \\
\text { weeks (Mean } \pm \text { SE) }\end{array}$} \\
\hline BAP & NAA & & & \\
\hline 0 & 0 & $7.25 \pm 0.47^{a}$ & $16.00 \pm 0.40^{\mathrm{a}}$ & $25.50 \pm 0.64^{\mathrm{a}}$ \\
\hline 0.5 & 0 & $7.75 \pm 0.47^{\mathrm{ab}}$ & $17.50 \pm 0.65^{b}$ & $25.75 \pm 0.75^{\mathrm{ab}}$ \\
\hline 1.0 & 0 & $8.25 \pm 0.47^{b}$ & $18.75 \pm 0.47^{c}$ & $26.50 \pm 0.64^{b}$ \\
\hline 1.5 & 0 & $8.25 \pm 0.47^{b}$ & $19.51 \pm 0.64^{\mathrm{d}}$ & $26.75 \pm 0.47 \mathrm{~b}$ \\
\hline 2.0 & 0 & $9.00 \pm 0.40^{c}$ & $19.75 \pm 0.47^{d}$ & $26.00 \pm 0.40^{b}$ \\
\hline 0 & 0.5 & $7.25 \pm 0.25^{\mathrm{a}}$ & $18.00 \pm 0.70^{\mathrm{bc}}$ & $26.25 \pm 0.47 \mathrm{~b}$ \\
\hline 0.5 & 0.5 & $8.25 \pm 0.47^{b}$ & $17.75 \pm 0.47 \mathrm{~b}$ & $25.75 \pm 0.25^{\mathrm{ab}}$ \\
\hline 1.0 & 0.5 & $8.00 \pm 0.40^{\mathrm{b}}$ & $19.00 \pm 0.40^{\mathrm{d}}$ & $25.25 \pm 0.47 \mathrm{a}$ \\
\hline 1.5 & 0.5 & $8.25 \pm 0.47^{b}$ & $19.00 \pm 0.91^{\mathrm{d}}$ & $25.50 \pm 0.64^{\mathrm{a}}$ \\
\hline 2.0 & 0.5 & $8.25 \pm 0.47^{\mathrm{b}}$ & $19.75 \pm 0.75^{\mathrm{d}}$ & $26.75 \pm 0.62^{\mathrm{b}}$ \\
\hline
\end{tabular}

Culture conditions: MS, $25 \pm 2^{\circ} \mathrm{C}, 27$ weeks of culture, $16 \mathrm{hrs}$ photoperiod and six replicates were used in each combination. The values with the same superscript are not significantly different at $\mathrm{p} \leq 0.05$.

The in vitro sown seeds developed into protocorms within 18 weeks of culture in $0.5 \mathrm{mg} / 1 \mathrm{NAA}$ containing medium and are differentiated into seedlings after 26 weeks (Fig. 3). Similar findings were also reported in previous studies on seeds germination of Aerides odorata (Pant and Gurung 2005), seed germination of Cymbidium sp., Dendrobium noblile and D. primulinum (Luan et al. 2006). This result is different from that reported for germination of Phaius tankervilliae seeds (Luan et al. 2006). 
In MS supplemented with $0.5 \mathrm{mg} / \mathrm{l}$ of BAP profuse development of protocorms was observed within the 17 weeks followed by seedling development within 26 weeks of seeds culture as compared to other tested concentrations of BAP (Fig. 4). The results reported here are in agreement with those of Epidendrum ibaguense (Hossain 2008) and Phaius tancarvilleae (Pant et al. 2011).
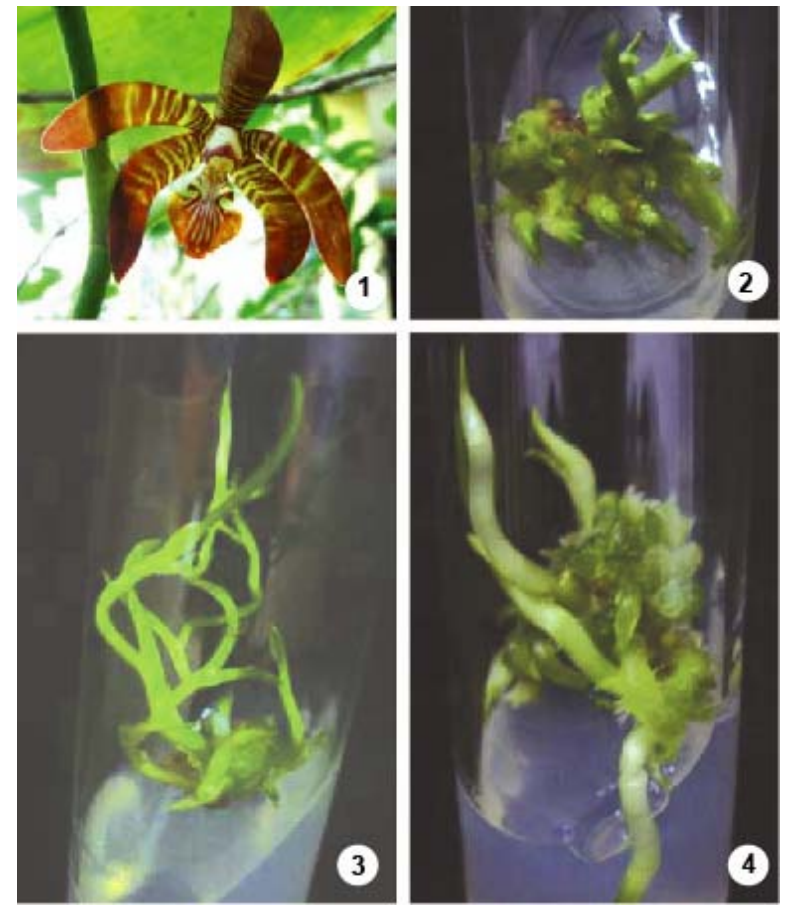

Figs 1-4: 1. A flower of E. clarkei. 2. Protocorms developed on MS.3. Seedlings developed on $0.5 \mathrm{mg} / \mathrm{l} \mathrm{NAA}$. 4 . Seedlings developed on $0.5 \mathrm{mg} / \mathrm{l} \mathrm{BAP}$.

In media supplemented with 1.0 - 2.0 BAP alone or fortified with a combination of $0.5-2.0 \mathrm{mg} / \mathrm{l}$ of BAP and NAA $0.5 \mathrm{mg} / \mathrm{l}$, delayed response both for the development of protocorms and seedlings from seeds was observed as compared to the other tested media.

\section{Acknowledgement}

The authors gratefully acknowledge the Central Department of Botany, Tribhuvan University, Kirtipur, Kathmandu, Nepal for providing laboratory facilities and UGC Nepal for partial financial support too. They also thank Mr. Anil Sharma for providing the plant material. 


\section{References}

Arditti J, Clementsm MA, Fast G, Hadley G and Nishimura, G (1982) Orchid seed germination and seedling culture - A manual. In: Orchid Biology -Reviews and perspectives, Vol II, Arditti J (Ed.), Cornell University Press, Ithaca, New York. pp. 243-370.

Ghimire M (2008) Epiphytic orchids of Nepal. Banko Janakari 18(2): 53-63.

Hossain MM (2008) Asymbiotic seed germination and in vitro seedling development of Epidendrum ibaguense Kunth. (Orchidaceae). African J. Biotech. 7(20): 3614-3619.

Johnson TR, Stewart SL, Dutra D, Kane ME and Richardson L (2007) Asymbiotic and symbiotic seed germination of Eulophia alta (Orchidaceae)-Preliminary evidence for the symbiotic culture advantage. Plant Cell Tiss. Organ Cult. 90: 313-323.

Knudson L (1922) Non-symbiotic germination of orchid seeds. Bot. Gaz. 73: 1-25.

Luan VQ, Thien NQ, Khiem DV and Nhut DT (2006) In vitro germination capacity and plant recovery of some native and rare orchids. Proceedings of International Workshop on Biotechnology in Agriculture. Nong Lam University Ho Chi Minh City, October 20-21.

Mitra GC (1986) In vitro culture of orchid seeds for obtaining seedlings. In: Biology, conservation and culture of orchids, Vij SP (Ed.), Affiliated East-West Press Private Ltd, New Delhi. p. 401.

Nayak NR, Chand PK, Rath SP and Patnaik SN (1998) Influence of some plant growth regulators on the growth and organogenesis of Cymbidium aloifolium (L.) Sw. Seed derived rhizomes in vitro. In vitro Cell. Dev. Biol. Plant. 34: 185-188.

Pant B and Gurung R (2005) In vitro seed germination and seedling development in Aerides odorata Lour. The J. Orchid Soc. India (TOSI). 19(1\&2): 51-55.

Pant B, Shrestha S and Pradhan S (2011) In vitro seed germination and seedling development of Phaius tancarvilleae (1' her.) Blume. Scientific world. 9(9): 50-52.

Stewart SL and Kane ME (2006) Asymbiotic seed germination and in vitro seedling development of Habenaria macroceratitis (Orchidaceae), a rare Florida terrestrial orchid. Plant Cell Tiss. Organ Cult. 86: 147-158.

Vij SP (2002) Orchids and tissue culture: Current status. In: Role of plant tissue culture in biodiversity conservation and economic development, Nandi SK, Palni LMS and Kumar A (Eds.), Gyanodaya Prakashan, Nainital, India. pp. 491-502. 